\title{
Potential prophylactic efficacy of mast cell stabilizers against COVID-19 vaccine-induced anaphylaxis
}

\author{
Itsuro Kazama*iD
}

\begin{abstract}
To fight against coronavirus disease 2019 (COVID-19), the vaccination is currently the most effective approach. However, in addition to common systemic side effects, the vaccines can cause serious allergic reactions or anaphylaxis. In anaphylaxis, the exposure to the allergen causes a sudden release of chemical mediators from mast cells, for which adrenaline is the drug of first choice. In our previous basic studies, in addition to adrenaline, anti-allergic drugs (olopatadine, loratadine, tranilast and ketotifen), antibiotics (clarithromycin), corticosteroids (hydrocortisone and dexamethasone) and certain food constituents (caffeine and catechin) inhibited the process of exocytosis and showed their effectiveness as highly potent mast cell stabilizers. In these studies, since mast cells were pre-incubated with these drugs or the food constituents before exocytosis was induced, the findings strongly indicated their prophylactic efficacy in stabilizing mast cells. Considering such pharmacological properties of these commonly prescribed medications or the food constituents, their prophylactic use may potentially be beneficial in preventing anaphylaxis caused by COVID-19 vaccination.
\end{abstract}

Keywords: Coronavirus disease 2019 (COVID-19), Vaccines, Anaphylaxis, Mast cell stabilizer

\section{To the editor,}

The Italian Society of Allergology, Asthma and Clinical Immunology (SIAAIC) has recently produced a series of indications to manage patients with allergic disorders during the Coronavirus disease 2019 (COVID-19) pandemic [1]. However, regarding the COVID-19 vaccineinduced allergic reactions, there are not enough clinical or experimental data to draw the guidelines to manage or prevent them.

COVID-19 causes severe acute respiratory syndrome and continues to spread around the world. Some patients develop fatal pneumonia or multiple organ failure due to generalized thrombotic microangiopathy as the result of cytokine storm [2]. Others, regardless the severity of

*Correspondence: kazamai@myu.ac.jp School of Nursing, Miyagi University, 1-1 Gakuen, Taiwa-cho, Kurokawa-gun, Miyagi 981-3298, Japan the disease, suffer from post-COVID syndrome which is characterized by persistent respiratory or systemic symptoms after recovery [3]. Recently, due to the predominancy of new severe acute respiratory syndrome coronavirus 2 (SARS-CoV-2) variants that are highly contagious, the number of seriously ill patients with COVID19 and their mortality rate are increasing $[4,5]$.

To fight against the virus and help stop the pandemic, the vaccination is currently the most effective approach [6]. According to recent studies, the administration of COVID-19 mRNA vaccines actually protected the individuals from the infection [7], prevented the onset of symptoms and reduced the severity of the disease with more than $90 \%$ efficacy rates $[8,9]$. However, in addition to common systemic side effects that are usually self-limited, including fever, headache, generalized fatigue and arthralgia [10], the vaccines, though rare, can cause serious allergic reactions or anaphylaxis, which is an acute, original author(s) and the source, provide a link to the Creative Commons licence, and indicate if changes were made. The images or other third party material in this article are included in the article's Creative Commons licence, unless indicated otherwise in a credit line to the material. If material is not included in the article's Creative Commons licence and your intended use is not permitted by statutory regulation or exceeds the permitted use, you will need to obtain permission directly from the copyright holder. To view a copy of this licence, visit http://creativecommons.org/licenses/by/4.0/. The Creative Commons Public Domain Dedication waiver (http://creativeco mmons.org/publicdomain/zero/1.0/) applies to the data made available in this article, unless otherwise stated in a credit line to the data. 
potentially life-threatening multisystem syndrome [1114]. In such cases, polyethylene glycol (PEG), one the ingredients of the vaccine, is considered to be responsible, since some patients were actually proven to be allergic to PEG $[15,16]$.

Concerning the mechanisms, the exposure to allergens, such as medications, foods and insect stings, causes a sudden release of chemical mediators from mast cells, including histamine, serotonin and leukotrienes. In the acute treatment, adrenaline, a non-specific adrenergic receptor agonist, is the drug of first choice, since the stimulation of $\alpha$ - and $\beta_{1}$-adrenergeic receptors reverses the cardiovascular collapse and ameliorates the airway obstruction [17]. Additionally, adrenaline quickly attenuates the serious allergic reaction fundamentally, since the stimulation of $\beta_{2}$-adrenergeic receptors directly suppresses further release of chemical mediators from mast cells $[18,19]$.

Antihistamines or corticosteroids are also used as adjunctive therapy to anaphylaxis after adrenaline administration [20]. Regarding the prevention of anaphylaxis, some studies recommended the prophylactic use of these drugs [21, 22]. Nevertheless, the results have been controversial or the benefits were limited to the allergic reaction caused by anesthetic agents [23]. In previous studies, by quantifying the amount of histamine released from mast cells, inhibitory effects of drugs or substances on the activity of mast cells were indirectly determined [24, 25]. However, to accurately determine the mast cell-stabilizing properties of these agents, the process of exocytosis itself should be examined directly. In this regard, by continuously monitoring the changes in the whole-cell membrane capacitance $(\mathrm{Cm})$ in mast cells, our recent patch-clamp study provided in vitro evidence that adrenaline dose-dependently inhibit the process of exocytosis [18]. This is based on the previous electrophysiological finding that the increase in the $\mathrm{Cm}$ represents the increase in the total cell surface area as a result of exocytosis [26] (Fig. 1). Therefore, the lack of increase in the $\mathrm{Cm}$ oppositely indicated the inhibition of exocytosis. In morphological analysis, being compatible with these findings, adrenaline actually suppressed the degranulation from mast cells dose-dependently, showing its effectiveness as a highly potent mast cell stabilizer (Fig. 2). In our experiments, mast cells that were freshly isolated from rat peritoneal cavity were initially preincubated with different concentrations of adrenaline for at least $10 \mathrm{~min}$. Then, compound 48/80 (final concentration $10 \mu \mathrm{g} / \mathrm{ml}$ ), the stimuli for exocytosis, were externally added. However, mast cells that were pre-incubated with relatively higher concentrations of adrenaline (100 mM, 1 $\mathrm{mM}$ ) were almost totally prevented from being degranulated [18] (Fig. 2). These findings clearly indicated the
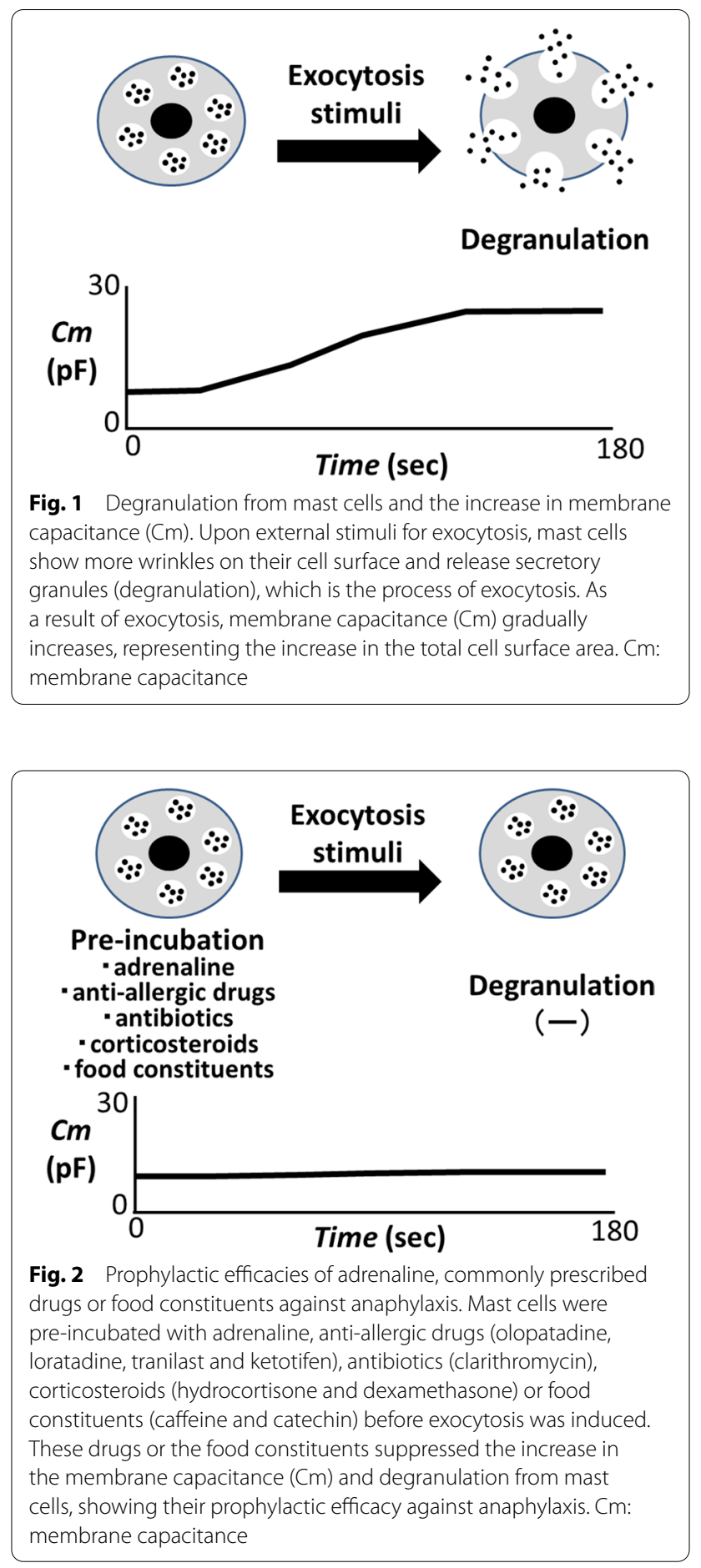

prophylactic aspect of adrenaline in stabilizing mast cells. Additionally, in our study, high dose prazosin, a selective $\alpha_{1}$-adrenergic receptor antagonist, synergistically potentiated such prophylactic efficacy of adrenaline [18].

Using the same approach, our series of patch-clamp studies also revealed the inhibitory effects of anti-allergic 
drugs (olopatadine, loratadine, tranilast and ketotifen), antibiotics (clarithromycin) and corticosteroids (hydrocortisone and dexamethasone) on the exocytotic process of mast cells [26-29] (Fig. 2). In our studies, mast cell-stabilizing properties of these drugs were quantitatively determined by the suppressed value of the $\mathrm{Cm}$, all of which showed dose-dependent inhibitory effects. In these studies, despite the external addition of exocytotic stimuli (compound 48/80), mast cells that were preincubated with these drugs were almost totally prevented from being degranulated, strongly showing their prophylactic efficacy in stabilizing mast cells [26-29]. Recently, we have additionally shown in in vitro study that both caffeine and catechin, that are main constituents of coffee and green tea, dose-dependently prevented the exocytotic process of mast cells [30]. In this study, we have further shown that low doses of catechin synergistically potentiated the mast cell-stabilizing property of caffeine.

COVID-19 vaccines containing PEG are contraindicated for individuals who have experienced prior allergic reaction to PEG [11]. Nevertheless, patients with mast cell diseases or individuals who have medical history of immediate allergic reactions to unidentified substances are allowed get vaccinated, as long as they are observed for $30 \mathrm{~min}$ following vaccination [11]. At present, regarding the prevention of COVID-19 vaccine-induced anaphylaxis, there are not enough clinical data to support the pretreatment effect of oral medications, such as antihistamines [11]. However, considering the findings obtained from our basic studies so far [26-30], the prophylactic use of the commonly prescribed medications (anti-allergic drugs, antibiotics and corticosteroids) or the food constituents (caffeine and catechin) may potentially be beneficial in preventing anaphylaxis caused by COVID-19 vaccination.

\section{Acknowledgements}

Not applicable.

\section{Authors' contributions}

IK interpreted the results and wrote the paper. The author read and approved the final manuscript.

\section{Funding}

This work was supported by the Salt Science Research Foundation, No. 2123 to IK.

\section{Availability of data and materials}

The data used to support the findings of this study are available from the corresponding author upon request.

\section{Declarations}

Ethics approval and consent to participate

In isolating mast cells from the peritoneal cavity of male Wistar rats, we profoundly anaesthetized the animals with isoflurane and sacrificed them by cervical dislocation. The protocols for the use of the animals were approved by the Animal Care and Use Committee of Miyagi University.
Consent for publication

Not applicable.

\section{Competing interests}

The authors declare that they have no competing interests.

Received: 12 August 2021 Accepted: 21 October 2021

Published online: 13 December 2021

\section{References}

1. Patella V, Delfino G, Florio G, Spadaro G, Chieco Bianchi F, Senna G, et al. Management of the patient with allergic and immunological disorders in the pandemic COVID-19 era. Clin Mol Allergy. 2020;18:18.

2. Kazama I. Targeting lymphocyte Kv1.3-channels to suppress cytokine storm in severe COVID-19: can it be a novel therapeutic strategy? Drug Discov Ther. 2020;14:143-4.

3. Kazama I. Stabilizing mast cells by commonly used drugs: a novel therapeutic target to relieve post-COVID syndrome? Drug Discov Ther. 2020;14:259-61.

4. Challen R, Brooks-Pollock E, Read JM, Dyson L, Tsaneva-Atanasova K, Danon L. Risk of mortality in patients infected with SARS-CoV-2 variant of concern 202012/1: matched cohort study. BMJ. 2021;372:n579.

5. Abdool Karim SS, de Oliveira T. New SARS-CoV-2 variants - clinical, public health, and vaccine implications. N Engl J Med. 2021;384:1866-8.

6. Olliaro P, Torreele E, Vaillant M. COVID-19 vaccine efficacy and effectiveness-the elephant (not) in the room. Lancet Microbe. 2021. https://doi. org/10.1016/S2666-5247(21)00069-0.

7. Angel Y, Spitzer A, Henig O, Saiag E, Sprecher E, Padova H, et al. Association between vaccination with BNT162b2 and incidence of symptomatic and asymptomatic SARS-CoV-2 infections among health care workers. JAMA. 2021. https://doi.org/10.1001/jama.2021.7152.

8. Anand P, Stahel VP. Review the safety of Covid-19 mRNA vaccines: a review. Patient Saf Surg. 2021:15:20.

9. Abu-Raddad LJ, Chemaitelly H, Butt AA. National Study Group for C-V. Effectiveness of the BNT162b2 Covid-19 vaccine against the B.1.1.7 and B.1.351 variants. N Engl J Med. 2021; https://doi.org/10.1056/NEJMc21049 7410.1056/NEJMc2104974.

10. Menni C, Klaser K, May A, Polidori L, Capdevila J, Louca P, et al. Vaccine side-effects and SARS-CoV-2 infection after vaccination in users of the COVID Symptom Study app in the UK: a prospective observational study. Lancet Infect Dis. 2021. https://doi.org/10.1016/S1473-3099(21)00224-3.

11. Turner PJ, Ansotegui IJ, Campbell DE, Cardona V, Ebisawa M, El-Gamal Y, et al. COVID-19 vaccine-associated anaphylaxis: a statement of the World Allergy Organization Anaphylaxis Committee. World Allergy Organ J. 2021;14:100517.

12. Shimabukuro TT, Cole M, Su JR. Reports of anaphylaxis after receipt of mRNA COVID-19 vaccines in the US-December 14, 2020-January 18, 2021. JAMA. 2021;325:1101-2.

13. Blumenthal KG, Robinson LB, Camargo CA Jr, Shenoy ES, Banerji A, Landman $A B$, et al. Acute allergic reactions to mRNA COVID-19 vaccines. JAMA. 2021;325:1562-5

14. Sampson HA, Munoz-Furlong A, Campbell RL, Adkinson NF Jr, Bock SA, Branum A, et al. Second symposium on the definition and management of anaphylaxis: summary report-Second National Institute of Allergy and Infectious Disease/Food Allergy and Anaphylaxis Network symposium. J Allergy Clin Immunol. 2006;117:391-7.

15. Giavina-Bianchi P, Kalil J. May polyethylene glycol be the cause of anaphylaxis to mRNA COVID-19 vaccines? World Allergy Organ J. 2021;14:100532.

16. Sellaturay P, Nasser S, Islam S, Gurugama P, Ewan PW. Polyethylene glycol (PEG) is a cause of anaphylaxis to the Pfizer/BioNTech mRNA COVID-19 vaccine. Clin Exp Allergy. 2021. https://doi.org/10.1111/cea.13874.

17. Cardona V, Ansotegui IJ, Ebisawa M, El-Gamal Y, Fernandez Rivas M, Fineman S, et al. World allergy organization anaphylaxis guidance 2020. World Allergy Organ J. 2020;13:100472.

18. Abe N, Toyama H, Ejima Y, Saito K, Tamada T, Yamauchi M, et al. Alpha 1-adrenergic receptor blockade by prazosin synergistically stabilizes rat peritoneal mast cells. Biomed Res Int. 2020;2020:3214186. 
19. Kemp SF, Lockey RF, Simons FE, World Allergy Organization ad hoc Committee on Epinephrine in A. Epinephrine: the drug of choice for anaphylaxis-a statement of the world allergy organization. World Allergy Organ J. 2008;1:18-26.

20. Shaker MS, Wallace DV, Golden DBK, Oppenheimer J, Bernstein JA, Campbell RL, et al. Anaphylaxis-a 2020 practice parameter update, systematic review, and Grading of Recommendations, Assessment, Development and Evaluation (GRADE) analysis. J Allergy Clin Immunol. 2020:145:1082-123

21. Kawano T, Scheuermeyer FX, Gibo K, Stenstrom R, Rowe B, Grafstein E, et al. $\mathrm{H1}$-antihistamines reduce progression to anaphylaxis among emergency department patients with allergic reactions. Acad Emerg Med. 2017:24:733-41.

22. Irani AM, Akl EG. Management and prevention of anaphylaxis. F1000Res. 2015. https://doi.org/10.12688/f1000research.7181.1.

23. Caffarelli C, Stringari G, Miraglia Del Giudice M, Crisafulli G, Cardinale F, Peroni DG, et al. Prevention of allergic reactions in anesthetized patients. Int J Immunopathol Pharmacol. 2011;24:91-9.

24. Graevskaya EE, Akhalaya MY, Goncharenko EN. Effects of cold stress and epinephrine on degranulation of peritoneal mast cells in rats. Bull Exp Biol Med. 2001;131:333-5.

25. Ng WH, Polosa R, Church MK. Adenosine bronchoconstriction in asthma: investigations into its possible mechanism of action. Br J Clin Pharmacol. 1990;30(Suppl 1):89S-98S
26. Baba A, Tachi M, Maruyama Y, Kazama I. Olopatadine inhibits exocytosis in rat peritoneal mast cells by counteracting membrane surface deformation. Cell Physiol Biochem. 2015;35:386-96.

27. Baba A, Tachi M, Ejima Y, Endo Y, Toyama H, Matsubara M, et al. Antiallergic drugs tranilast and ketotifen dose-dependently exert mast cellstabilizing properties. Cell Physiol Biochem. 2016;38:15-27.

28. Mori T, Abe N, Saito K, Toyama H, Endo Y, Ejima Y, et al. Hydrocortisone and dexamethasone dose-dependently stabilize mast cells derived from rat peritoneum. Pharmacol Rep. 2016;68:1358-65.

29. Kazama I, Saito K, Baba A, Mori T, Abe N, Endo Y, et al. Clarithromycin dose-dependently stabilizes rat peritoneal mast cells. Chemotherapy. 2016;61:295-303.

30. Yashima M, Sato Y, Kazama I. Catechin synergistically potentiates mast cell-stabilizing property of caffeine. Allergy Asthma Clin Immunol. 2021;17:1.

\section{Publisher's Note}

Springer Nature remains neutral with regard to jurisdictional claims in published maps and institutional affiliations.
Ready to submit your research? Choose BMC and benefit from:

- fast, convenient online submission

- thorough peer review by experienced researchers in your field

- rapid publication on acceptance

- support for research data, including large and complex data types

- gold Open Access which fosters wider collaboration and increased citations

- maximum visibility for your research: over 100M website views per year

At BMC, research is always in progress.

Learn more biomedcentral.com/submissions 